\title{
Nina Ogińska-Bulik, „Pozytywne skutki doświadczeń traumatycznych, czyli kiedy łzy zamieniają się w perły", Wydawnictwo Difin, Warszawa 2013
}

Książka Niny Ogińskiej-Bulik jest, jak do tej pory, jedyną polską publikacją poruszającą zagadnienie potraumatycznego wzrostu. Autorka od lat skupia swoje zainteresowania na problematyce psychologii zdrowia i stresu. Konstrukt będący przedmiotem jej dociekań stanowi jeden z centralnych obszarów badań w obrębie orientacji salutogenetycznej, skupiającej się na poszukiwaniu czynników sprzyjających zachowaniu dobrego zdrowia i samopoczucia pomimo doświadczanych trudności.

Ostatnimi czasy społeczeństwo boryka się z wieloma problemami dotykającymi naszą cywilizację, takimi jak: kryzys gospodarczy, coraz większa zapadalność na choroby psychiczne czy życie w chronicznym stresie. Ponadto każdy z nas jest narażony na doświadczanie osobistych wydarzeń o charakterze stresogennym czy traumatycznym takich jak: utrata pracy, śmierć bliskiej osoby, rozwód, choroba somatyczna, doznawanie przemocy czy bycie uczestnikiem, bądź świadkiem wypadków komunikacyjnych. Dlatego, tym większą uwagę powinniśmy kierować ku temu i tym szerszym polem do eksploracji dla badaczy powinno być to, co może wspomóc nas w skutecznym radzeniu sobie $z$ takimi sytuacjami. Wiele wiadomo już o negatywnych skutkach zdarzeń traumatycznych a niestety wciąż za mało zbadane są procesy resilience i potraumatycznego wzrostu. Ogińska-Bulik próbuje znaleźć odpowiedź na pytanie, co powoduje, że niektórzy z nas, z ciężkiej sytuacji potrafią wyjść silniejsi niczym mityczny Feniks odradzający się z popiołów.

Praca składa się z czterech rozdziałów. Na początku Autorka porusza zagadnienie stresu i traumy oraz stara się pokazać wzajemne powiązania między tymi dwoma pojęciami. Wymienia różne typologie pojęcia stresu, 
który może być rozumiany jako: reakcja, bodziec bądź relacja między jednostką a otoczeniem. W odniesieniu do zagadnienia potraumatycznego wzrostu, opowiada się za bodźcową koncepcją stresu rozumianą jako występowanie zdarzeń wywołujących w organizmie człowieka stan napięcia. Porusza kwestię stresorów, które dzieli na trzy grupy: kataklizmy (np. klęska żywiołowa, wojna, atak terrorystyczny), stresory osobiste (zwolnienie z pracy, rozwód, śmierć współmałżonka, ale i zawarcie małżeństwa czy narodziny dziecka $w$ rodzinie) oraz stresory drugoplanowe, czyli tzw. trudy dnia codziennego. Następnie zajmuje się omówieniem pojęcia traumy, które doczekało się wielu sposobów konceptualizacji wraz z tym jak aktualizowała się lista Międzynarodowej Klasyfikacji Chorób (DSM). Możemy się spotkać z twierdzeniem, że trauma to zdarzenie znajdujące się poza zakresem normalnych ludzkich reakcji, które byłoby istotnie zakłócające dla prawie wszystkich ludzi, czy też rozumieniem jej jako urazu będącego źródłem negatywnego napięcia psychicznego wywołującego silne emocje i trwały ślad w psychice, prowadzące do zaburzeń w zachowaniu (s.13). Jak jednak podkreśla Ogińska-Bulik, w każdej z tych definicji najistotniejsze jest to, że efektem zdarzenia traumatycznego są silne negatywne emocje w postaci strachu i przerażenia, które mogą prowadzić do zespołu stresu ostrego czy zespołu stresu pourazowego (PTSD), i właśnie możliwością wystąpienia tych przykrych konsekwencji trauma różni się od stresu. Poruszana jest również kwestia częstości występowania zdarzeń traumatycznych. Autorka przytacza wyniki badań amerykańskich oraz szwedzkich, z których wynika, że doświadczanie takich wydarzeń jest dość powszechne w różnych kręgach kulturowych. Odwołuje się także do rozlicznych badań dotyczących występowania takich sytuacji u dzieci i młodzieży. Konstatuje, że jest ich istotnie więcej niż w przypadku osób dorosłych a należą do nich m.in. nadużycia seksualne, przemoc w środowisku domowym, śmierć kogoś bliskiego, gwałt, przedwczesne macierzyństwo czy choroba. Na koniec pierwszego rozdziału Autorka zajmuje się szerzej pojęciem zespołu stresu pourazowego (PTSD), będącym najpoważniejszym skutkiem doznania zdarzeń traumatycznych, które w ostatnich latach spotykają się z dużym zainteresowaniem, także wśród polskich badaczy, ze względu na masowe rozpoznawanie tego zaburzenia u żołnierzy wracających z wojny. Aby mówić o PTSD konieczne jest występowanie przez ponad miesiąc trzech grup objawów: powracających snów, wspomnień dotyczących traumy, czyli tzw. intruzji, uporczywego unikania bodźców i sytuacji skojarzonych z traumą oraz podwyższonego pobudzenia psychofizjologicznego wyrażającego się np. bezsennością czy dekoncentracją. Jak wyjaśnia Ogińska-Bulik, wystąpienie tego rodzaju zabu- 
rzenia jest uzależnione od rodzaju zdarzenia traumatycznego - największe prawdopodobieństwo u dorosłych występuje w przypadku gwałtu a u dzieci w wyniku doznanej przemocy fizycznej bądź seksualnej. Autorka wymienia cztery możliwe konsekwencje przeżytej traumy, do których należą:

a) poddanie się - brak adaptacji do zaistniałej sytuacji,

b) przetrwanie - funkcjonowanie, ale na poziomie niższym niż przed traumą,

c) resilience ( prężność) - pozytywna adaptacja,

d) potraumatyczny wzrost - poziom funkcjonowania jednostki jest wyższy niż przed traumą. I to właśnie ostatni sposób reakcji na traumę, który jest jednocześnie tematem kolejnego rozdziału stanowi przedmiot rozważań pozostałej części publikacji.

W tej części Ogińska-Bulik szerzej omawia zagadnienie wzrostu potraumatycznego, sposoby jego konceptualizacji oraz prezentuje wyniki własnych badań, w których wykorzystuje ów konstrukt. Zestawia je z pojęciami bliskoznacznymi takimi jak twardość czy resilience, z którymi jest on najczęściej porównywany.

Autorka stara się wykazać różnicę pomiędzy potraumatycznym wzrostem (posttraumatic growth) - terminem wprowadzonym do literatury w 1996 roku przez Tedeschiego i Calhouna, oznaczającego występowanie pozytywnych zmian w osobowości i zachowaniu jednostki, w wyniku podejmowania prób poradzenia sobie z następstwami traumatycznych wydarzeń życiowych oraz pojęciem rezyliencji (resilience), którego wprowadzenie zawdzięczamy małżeństwu Blocków (Block, Block 1980), rozumianym jako proces pozytywnej adaptacji w obliczu trudności życiowych lub właściwość osobowości pozwalająca na skuteczne radzenie sobie z trudnościami (wtedy mówimy o ego resiliency). Według Ogińskiej-Bulik potraumatyczny wzrost jest związany z lepszym funkcjonowaniem niż przed traumą, a rezyliencja oznacza tylko pozytywną adaptację bez konieczności rozwoju cech swojej osobowości. Poza tym, potraumatyczny wzrost nie jest tożsamy z przystosowaniem do trudnej sytuacji, co jest charakterystyczną cechą jednostek rezylientnych. I wreszcie, wzrost jest związany z przewartościowaniem swojego życia, co nie jest warunkiem koniecznym przy procesach resilience.

Autorka opisuje również modele wzrostu po traumie, które traktują go jako rezultat radzenia sobie ze zdarzeniem traumatycznym bądź jako sposób radzenia sobie. Najwięcej miejsca poświęca modelowi zaproponowanemu przez twórców konstruktu, którzy opowiadają się za ujmowaniem go w kategoriach skutku poradzenia sobie z traumą. Zakładają oni, że u podstaw wzrostu leżą te same procesy psychologiczne, co przy występowaniu nega- 
tywnych skutków zdarzenia traumatycznego. Według Tedeschiego i Calhouna zdarzenie traumatyczne jest dla człowieka jak trzęsienie ziemi, w wyniku którego jednostka traci wszystko, co do tej pory uważała za ważne i sensowne, powoduje to konieczność odnalezienia się w nowej, ,,potraumatycznej" rzeczywistości. Wzrost jest żmudnym procesem i zachodzi u człowieka $\mathrm{w}$ momencie, gdy zaczyna on przypisywać negatywnym zdarzeniom znaczenie, które w efekcie zostaje przekształcone w istotną dla niego wartość. W dalszej części rozdziału Ogińska-Bulik omawia pokrótce czynniki warunkujące wzrost potraumatyczny, dzieląc je na: sytuacyjne, czyli dotyczące samej traumy, do których zalicza jej rodzaj, intensywność, stopień zagrożenia dla zdrowia i życia, czas jaki upłynął od wydarzenia i wsparcie społeczne oraz czynniki podmiotowe, czyli właściwości osobowościowe, strategie radzenia sobie ze stresem, przekonania jednostki i właściwości socjodemograficzne. Następnie Autorka posiłkując się rozlicznymi wynikami badań, stara się ustalić wpływ poszczególnych czynników na pojawienie się wzrostu potraumatycznego. Dokonuje omówienia narzędzi służących do pomiaru natężenia rzeczonego pojęcia jak np. Kwestionariusza Wzbogacenia Doświadczenia Osobistego autorstwa Kaniastego złożonego z 22 pytań, The Stress Related Gross Scale (SRGS) złożonego z 50 itemów, The Posttraumatic Growth Inventory (PTGI) autorstwa Tedeschiego i Calhouna składającego się z 25 pozycji, który analizuje poziom wzrostu potraumatycznego na pięciu poziomach, do których zaliczamy: relacje z innymi, dostrzeganie nowych możliwości, poczucie osobistej siły, zmiany duchowe i docenianie życia. I choć jak nadmienia Autorka, kwestionariusz ten spotykał się z wieloma zarzutami takimi jak: niejednoznaczność, brak szerszego wyjaśnienia stosowanych pojęć oraz niedocenianie roli innych czynników, jest on najczęściej stosowanym narzędziem do pomiaru tej właściwości i to właśnie na jego podstawie Ogińska-Bulik stworzyła 21-itemowy Inwentarz Potraumatycznego Rozwoju (IPR). Sprawdza on poziom wzrostu na czterech skalach: zmian $\mathrm{w}$ percepcji siebie, zmian $\mathrm{w}$ relacjach $\mathrm{z}$ innymi, większego doceniania życia oraz zmian duchowych. Jak jednak zaznacza, wzrost potraumatyczny można również badać posługując się metodami jakościowymi, takimi jak wywiad czy technika narracyjna, choć nie dostarczają one tak pewnych wyników jak podane wyżej kwestionariusze. Na zakończenie drugiego rozdziału Autorka prezentuje własne badania przeprowadzone na grupie 366 osób, które doświadczyły zdarzeń traumatycznych związanych ze śmiercią bliskiej osoby, zawałem serca oraz stresem wynikającym z rodzaju wykonywanej pracy. W swoich badaniach brała pod uwagę wpływ takich czynników jak: temperament, prężność, duchowość, wsparcie społeczne, poczucie sensu ży- 
cia, strategie radzenia sobie ze stresem oraz zadowolenie z życia. Najsilniej ze wzrostem korelowało poczucie sensu życia i duchowość. Ogińska-Bulik wskazuje jednak na pewne ograniczenie tych wyników ze wzgląd na: małą grupę badanych, koncentrację na pojedynczych związkach między zmiennymi a potraumatycznym wzrostem zamiast analizowania złożonych relacji między samymi zmiennymi oraz metodę badania, którą były techniki oparte na samoopisie, co mogło według Autorki powodować u badanych pokusę do pokazania się w lepszym świetle. Jak podkreśla, owe ograniczenia są przedmiotem do refleksji i stanowią asumpt ku dalszym badaniom.

Trzeci rozdział poświęcony jest występowaniu zjawiska wzrostu po traumie u dzieci i młodzieży. Zawiera próbę wyjaśnienia zasad funkcjonowania mechanizmu wzrostu potraumatycznego u tej grupy, podaje możliwe uwarunkowania wzrostu oraz prezentuje badania przeprowadzone na grupie 380 dzieci. W podrozdziale traktującym o mechanizmach wzrostu u dzieci i młodzieży Autorka stwierdza, że przebiega on w taki sam sposób jak u osób dorosłych, ale ze względu na słabo ukształtowane schematy poznawcze i kształtującą się osobowość może być trudniejszy do osiągnięcia. Następnie podaje czynniki, które bierze się pod uwagę przy badaniu tej grupy pod kątem wzrostu potraumatyczego. Tak jak i mechanizmy wzrostu, nie różnią się one znacząco od analizowanych przy badaniu osób dorosłych. Jako narzędzie służące do pomiaru tej właściwości u najmłodszych Ogińska-Bulik wymienia Posttraumatic Growth Inventory for Children (PTGI-C) mierzący tę cechę na pięciu poziomach, do których należą: nowe możliwości, relacje z innymi, osobista siła, docenianie życia i zmiany duchowe. Autorka podkreśla, że wciąż mamy niewiele takich narzędzi i kwestia ta wymaga dalszych dociekań. Jak dodaje, jedynym inwentarzem służącym do badania tej właściwości w Polsce jest Kwestionariusz Osobowego Wzrostu stworzony przez Ogińską-Bulik przeznaczony dla dzieci powyżej 10 roku życia, który dzieli się na trzy podskale: zmiany w percepcji siebie, docenianie życia oraz relacje $\mathrm{z}$ innymi. Podobnie jak w poprzednim rozdziale, tak i w tym Autorka prezentuje wyniki własnych badań, w których starała się ustalić, co w największym stopniu decyduje o pojawieniu się potraumatycznego wzrostu u dzieci i młodzieży. Osoby będące przedmiotem badań doświadczyły negatywnych wydarzeń życiowych takich jak: wypadek drogowy, katastrofa naturalna (powódź), pozbawienie opieki rodzicielskiej i umieszczenie w domu dziecka oraz doznanie przemocy. W odróżnieniu od badań przedstawionych rozdział wcześniej, rodzaj doznanej krzywdy odgrywał istotną rolę w procesie potraumatycznego wzrostu. Największe nasilenie pozytywnych skutków wykazano u młodzieży, która doświadczyła utraty opieki rodzicielskiej 
i została umieszczona w placówce opiekuńczo- wychowawczej a najmniejsze u tej grupy, która była ofiarą katastrofy naturalnej. Duże znaczenie miał również wpływ takich cech jak: stosowane strategie radzenia sobie ze stresem, poczucie własnej wartości, koherencji, skuteczności oraz prężność, która co ciekawe u osób dorosłych nie odgrywała znaczącej roli. Autorka wskazuje jednak na ograniczenia tego samego rodzaju, co w przypadku badań prowadzonych wśród osób dorosłych zachęcając do dalszej eksploracji, w której można by np. wziąć pod uwagę znaczenie procesów poznawczych, zwłaszcza ruminacji oraz rozszerzyć katalog korzyści płynących z doświadczania zdarzeń traumatycznych. To, co jest jednak najważniejsze to fakt, że Ogińskiej-Bulik udało się wykazać, że w ludziach, także i tych najmłodszych jest potencjał ku temu, by zamieniać łzy w perły.

Ostatni rozdział przeznaczony jest przede wszystkim dla praktyków czy terapeutów mogących wykorzystać wnioski płynące z badań nad uwarunkowaniami wzrostu potraumatycznego $\mathrm{w}$ pracy $\mathrm{z}$ osobami, które doznały traumy oraz $\mathrm{w}$ działaniach profilaktycznych wobec osób szczególnie narażonych na pojawienie się przykrych konsekwencji np. ze względu na wykonywaną pracę. Autorka wymienia techniki pracy stosowane w terapii, wśród których prym wiedzie terapia poznawczo-behawioralna pozwalająca pacjentowi zrozumieć sposób, w jaki negatywne myśli dotyczące zdarzenia traumatycznego wpływają na występowanie negatywnych emocji, takich jak lęk czy poczucie winy. Dzięki ich rozpoznaniu oraz zmiany nastawienia jest $\mathrm{w}$ stanie postawić sobie nowe cele i uporać się z traumą, co może prowadzić do pojawienia się korzystnych zmian potraumatycznych. Jako inne formy leczenia podaje również: terapię farmakologiczną oraz grupową, którą szczególnie chwali za możliwość podzielenia się swoimi przeżyciami z innymi i eliminację poczucia osamotnienia z problemem. Ogińska-Bulik sugeruje, by w ramach programów profilaktycznych większą uwagę poświęcano kształtowaniu refleksyjności, która wzmaga angażowanie się w poszukiwanie nowych punktów widzenia w momencie znalezienia się w trudnej sytuacji. Ponadto nawołuje do rozwoju osobowości, odwołując się do teorii zachowania zasobów Hobfolla czy koncepcji mobilizacji osobistych potencjałów zdrowia Juczyńskiego, które mówią o konieczności gromadzenia zapasu sił, aby w obliczu trudnej sytuacji mieć z czego skorzystać. Autorka omawia również niewielki repertuar programów mających na celu promocję wzrostu po traumie. Większość z nich jest nastawiona przede wszystkim na kształtowanie umiejętności wyrażania emocji oraz korzystania ze wsparcia społecznego. Jako przykładowe metody ekspresji emocji Ogińska-Bulik podaje nie tylko mówienie o samej sytuacji, ale i prowadzenie bloga czy pamiętnika, 
które może pomóc jednostce w rozpoznaniu jej emocji, myśli, uporządkowaniu ich i spojrzenia na nie $z$ dystansem. Radzi również, by wyznaczać sobie rozmaite cele, zadania i zapisywać je, bo to zwiększa szansę na ich realizację.

Na zakończenie Nina Ogińska-Bulik kieruje apel do Czytelników, którzy mogą odczuwać pewien dyskomfort w sytuacji, gdy ktoś stara się im powiedzieć, że śmierć bliskiej osoby może być okazją do wzrostu osobowego i zmiany życia na lepsze. Jak zaznacza, w naszej kulturze wciąż jest ona tematem tabu i dla wielu osób stanowi jedynie podstawę do przeżywania żałoby. Autorka chce w ten sposób uwrażliwić ludzi na to, że trauma może przynosić różnorodne konsekwencje i nie zawsze muszą być one negatywne, a osoby doświadczające pozytywnych skutków wydarzeń traumatycznych nie powinny spotykać się z potępieniem ze strony otoczenia.

Praca Niny Ogińskiej-Bulik jest niezwykle ważną i unikatową publikacją w obrębie psychologii zdrowia, a zwłaszcza jej najmłodszej siostry, czyli psychologii pozytywnej i dlatego niewątpliwie zasługuje na uwagę Czytelników zainteresowanych tą tematyką. Stanowi obszerne kompendium wiedzy o tym, co może wspomóc nas $\mathrm{w}$ radzeniu sobie $\mathrm{z}$ trudnościami i to nie tylko tymi traumatycznymi jak klęska żywiołowa czy wojna, ale i tymi, które są udziałem każdego z nas w codziennym życiu. Jest napisana $\mathrm{w}$ jasny i przystępny sposób, co jest jej ogromnym walorem i w niczym nie ujmuje jej wartości, dzięki czemu nawet osoby słabo zorientowane $\mathrm{w}$ tematyce, a zainteresowane zgłębieniem procesów potraumatycznego wzrostu nie będą miały problemu ze zrozumieniem treści, co niestety jest częstą cechą publikacji naukowych i odwodzi od zaglądania do takich pozycji. A szkoda! Wnioski płynące z badań zaprezentowanych przez Autorkę stanowią nie tylko cenne źródło informacji dla psychologów, trenerów, lekarzy psychiatrów czy psychoterapeutów, ale i dla każdego, kto chciałby zbudować w sobie umiejętność do zamiany łez w perły.

Małgorzata Rutkowska 